\title{
First records of freshwater fish species in Colombia: extending the distribution of Amazonian and Orinoco fish species
}

\author{
Juan D. Bogotá-Gregory ${ }^{1,2}$, Flávio C. T. Lima ${ }^{3}$, Carlos DoNascimiento ${ }^{4}$, Astrid Acosta-Santos ${ }^{1}$, \\ Francisco A. Navarro-Villa ${ }^{5}$, Edwin Agudelo Córdoba ${ }^{1}$
}

\begin{abstract}
1 Instituto Amazónico de Investigaciones Científicas Sinchi, Grupo de Ecosistemas Acuáticos, Avenida Vásquez cobo entre calles 15 y 16, Leticia, Amazonas, Colombia. 2 University of Central Florida, Department of Biology, 4110 Libra Dr, Orlando, FL 32816, USA. 3 Museu de Zoologia da Universidade Estadual de Campinas "Adão José Cardoso", Campinas, Sao Paulo, Caixa Postal 6109, 13083-863, Campinas, SP, Brazil. 4 Instituto de Investigación de Recursos Biológicos Alexander von Humboldt, Claustro de San Agustín, Carrera 8 \# 15 - 08, Villa de Leyva, Boyacá, Colombia. 5 Universidad del Tolima, Facultad de Ciencias, Grupo de Investigación en Zoología, barrio Santa Helena, Ibagué, Tolima, Colombia. Corresponding author: Juan D. Bogotá-Gregory, juandbogota@gmail.com
\end{abstract}

\begin{abstract}
Based on a rigorous analysis of fish collections of the Instituto Amazónico de Investigaciones Científicas (Sinchi) and new collections by us, we report new Colombian records and geographical range extensions for freshwater fish species. The new occurrences include representatives of four taxonomic orders, eight families, and 13 genera. Our findings expand the geographic ranges of fish species within the Amazon and Orinoco basins and include species reported from Colombia for the first time. This information is fundamental for completion of species inventories, as well as analyses of freshwater fish diversity patterns at macroecological scales. In addition, our data provide useful information for the formulation of strategies for the conservation, management, and sustainable use of biodiversity.
\end{abstract}

\section{Keywords}

Cis-Andean, freshwater ichthyofauna, geographical distribution, Neotropics, range extensions.

Academic editor: Felipe Ottoni | Received 7 April 2020 | Accepted 3 October 2020 | Published 28 August 2020

Citation: Bogotá-Gregory JD, Lima FCT, DoNascimiento C, Acosta-Santos A, Navarro-Villa FA, Córdoba EA (2020) First records of freshwater fish species in Colombia: extending the distribution of Amazonian and Orinoco fish species. Check List 16 (5): 1395-1406. https://doi.org/10.15560/16.5.1395

\section{Introduction}

Scientific reference collections are important tools for biodiversity inventories (Schindel and Cook 2018; Watanabe 2019). They provide information used by different specialists across various disciplines including ecology, biogeography, taxonomy, and systematics (Humboldt 2000; Lomolino et al. 2010; DoNascimiento et al. 2017). The role of scientific collections in systematics and taxonomy is fundamental for species descriptions, assessments of evolutionary relationships, and as a comparative model for biodiversity (Papavero 1999; Seberg et al. 2003). Scientific collections not only provide recent data, but also historical information dating back hundreds of years (Chapman and Busby 1994). This information helps to better understand geographical ranges of organisms and provides a basis for the formulation of strategies for the conservation, management, and sustainable use of biodiversity (Arbeláez-Cortés et al. 2017).

The Colección Ictiológica de la Amazonian Colombiana (CIACOL), is part of the scientific reference collections of the Instituto Amazónico de Investigaciones 
Científicas (Sinchi) at Leticia, Amazonas, Colombia. The Sinchi Institute in Colombia is a scientific governmental agency that promotes the collection and distribution of the biological information of the Colombian Amazon. Just recently, the Aquatic Ecosystems Group of the Sinchi Institute have reinforced interinstitutional partnerships with other research institutes and local agencies to document the highest freshwater fish diversity in the world, the Amazonian ichthyofauna (Lundberg 2001). The CIACOL is composed of specimens collected in the Amazon Biome following Sinchi's definition of hydrographic, biogeographic, and administrative areas. Following the biogeographic classification proposed by Morrone (2006), the Amazon biome in Colombia corresponds to the area covered predominantly by dense moist tropical forest and located within the Amazonian subregion. At present, the CIACOL is composed of almost 4050 lots of fish collected from the Amazon, Putumayo, Caquetá, Apaporis, Vaupés, Inírida, and Guaviare river drainages. The geographical origin of the biological material in collections is important because it highlights areas in which very few ichthyological studies have been done.

Like many taxonomies (Prance 1994), Neotropical ichthyology has become a dynamic field of study in the second half of the last century, with a clear emphasis on systematics and species descriptions (Reis et al. 2016). The humid Neotropics is home to the most diverse ichthyofauna on Earth (Lundberg 2001; Reis et al. 2003; Junk et al. 2007; Leveque et al. 2008; Pimm et al. 2014; Ferraris et al. 2017). The proliferation of surveys in remote unexplored areas, where the aquatic ecosystems of the Amazon hosts high species diversity and endemicity, has increased this number even more. The results of our taxonomic revision expand 16 distribution ranges within the Amazon and Orinoco basins at a drainage scale and include 16 species reported from Colombia for the first time. Our study is based on a rigorous analysis of fish collections at the CIACOL and new collections carried out by us. The results of this study will be useful to a disparate community of researchers interested in the tropical aquatic diversity, including those in the fields of natural history, biogeography, evolutionary biology, systematics, and taxonomy. The species distributions are fundamental not only for completion of species inventories, but also the foundation for analyses at macroecological scale to better understand the processes that influence distribution patterns in highly diverse biotas (Lomolino et al. 2010; Burley et al. 2016).

Natural ecosystems in the Amazon Region are increasingly threatened by habitat loss, overfishing, hydroelectric dams, and climate change (Abell et al. 2008; Castello et al. 2013; Röpke et al. 2017). Understanding the spatial patterns of fish distributions provides essential information for mitigating the effects of anthropogenic changes over fish communities. Detailed knowledge of species distributions at different temporal and spatial scales are essential for conservation, as management plans are often far from completion due to lack of baseline information.

\section{Methods}

The new records reported herein were derived from a rigorous analysis of the fish deposited at the CIACOL and recent field work carried out by us. The CIACOL specimens were collected by the Aquatic Ecosystems Group of the Sinchi Institute in various sampling programs under the framework of the project "Conservación y Aprovechamiento Sostenible de la Diversidad Biológica, Socioeconómica y Cultural de la Amazonia Colombiana Amazonas, Caquetá, Putumayo, Guaviare, Vaupés, Guainía”. Sinchi is a research institute created in 1993 affiliated to the Ministry of Environment and Sustainable Development, with jurisdiction over the territory of the Colombian Amazon. One of the main functions of the Sinchi is to perform and promote the inventory of Amazon region flora and fauna, to establish collections and data banks, and promote research. The collection of specimens is made under the umbrella of a global research permit issued by the above-mentioned ministry.

Fish catches pertaining specimens from the Amazonian piedmont were done by researchers of the Sinchi Institute using a SAMUS $725 \mathrm{M}$ electrofisher. For the remaining areas, the Amazonian lowlands, conventional beach seines of different dimensions (all $5 \mathrm{~mm}$ eye mesh) were used by researchers of the Sinchi Institute and others. The specimens were euthanized with clove oil and fixed in 10\% formaldehyde solution. Once specimens were fixed, they were transferred to $70 \%$ ethanol for taxonomic identification and storage in the CIACOL. We identified the species using descriptions and keys from taxonomic literature on fish from the Amazon and Orinoco basins. We followed the taxonomy and classification system adopted by Fricke et al. (2020). Museum acronyms follow Sabaj (2016). Previously published records were checked using Reis et al. (2003), DoNascimiento et al. (2017), and Fricke et al. (2020). Localities referenced herein were recorded using a GPS with WGS 1984 geodetic datum. To report geographic range extensions, we compared our new records with the nearest occurrences, using hydrological distances and not linear distances, since only the aquatic network serves as corridors for fishes.

\section{Results}

New records are reported for freshwater fish species. These include representatives of four taxonomic orders, eight families and 13 genera. Our findings expand distribution ranges within the Amazon and Orinoco basins and include newly recorded species from Colombia.

Order Characiformes

Family Crenuchidae 


\section{Characidium crandellii Steindachner, 1915}

Figures 1A, 2A

New records. COLOMBIA • 12 adults; Vaupés, Municipality of Mitú, río Paca tributary of the río Vaupés, Cachivera Muela near Acaricuara community; $00.7130^{\circ} \mathrm{N}, 070.2603^{\circ} \mathrm{W}$; ca $180 \mathrm{~m}$ a.s.1.; 22 Nov. 2012; Astrid Acosta, Jesús Dámaso and Fray León leg.; found at a rapid; voucher CIACOL 961.

Identification. Characidium crandelli is distinguished from all remaining Characidium species, except $C$. declivirostre, in lacking scales ventrally from the isthmus to the insertion of the pelvic fins (Buckup 1993). Specimens from the rio Teles Pires were identified as Characidium aff. crandelli using tooth morphology (tricuspid teeth in C. crandelli vs unicuspid teeth in C. declivirostre) and circumpeduncular scales (10 circumpeduncular scales in C. crandelli vs 12 in C. declivirostre) (Ohara et al. 2017). We used this same rationale to identify our specimens as $C$. crandelli. A revisionary study of these highly specialized rheophilic fishes is still necessary.

Previously known distribution. Brazil: upper rio Negro basin (Lima et al. 2005), rio Madeira basin (FlausinoJunior et al. 2016), and Rio Tapajós basin (Ohara et al.
2017), all state of Amazonas. Type locality: rio Miang and rio Branco, Brazil.

Remarks. The species is broadly distributed in rapids throughout the Amazon Basin. This species was already recorded from Colombia by GBIF (https://www.gbif.org/ occurrence/search?country=CO\&taxon_key=2352371); however, this is the first time that it is reported by a published paper.

\section{Order Characiformes}

Family Anostomidae

\section{Leporinus altipinnis Borodin, 1829}

Figures 1B, 2B

New records. COLOMBIA $\bullet 1$ adult; Guainía, Municipality of Inírida, río Inírida, laguna Brujas; $03.4649^{\circ} \mathrm{N}$, 067.9555 ${ }^{\circ}$ W; ca $80 \mathrm{~m}$ a.s.1.; 10 Dec. 2014; Jhonatan Quiñonez and Marcela Nuñez leg.; found in a blackwater lake; voucher CIACOL 1520 .

Identification. Leporinus altipinnis is unique among its congeners in possessing 13 or 14 vertical bars in adult (>200 mm SL) specimens. The remaining Leporinus species present vertical at most nine or 10 bars on the body

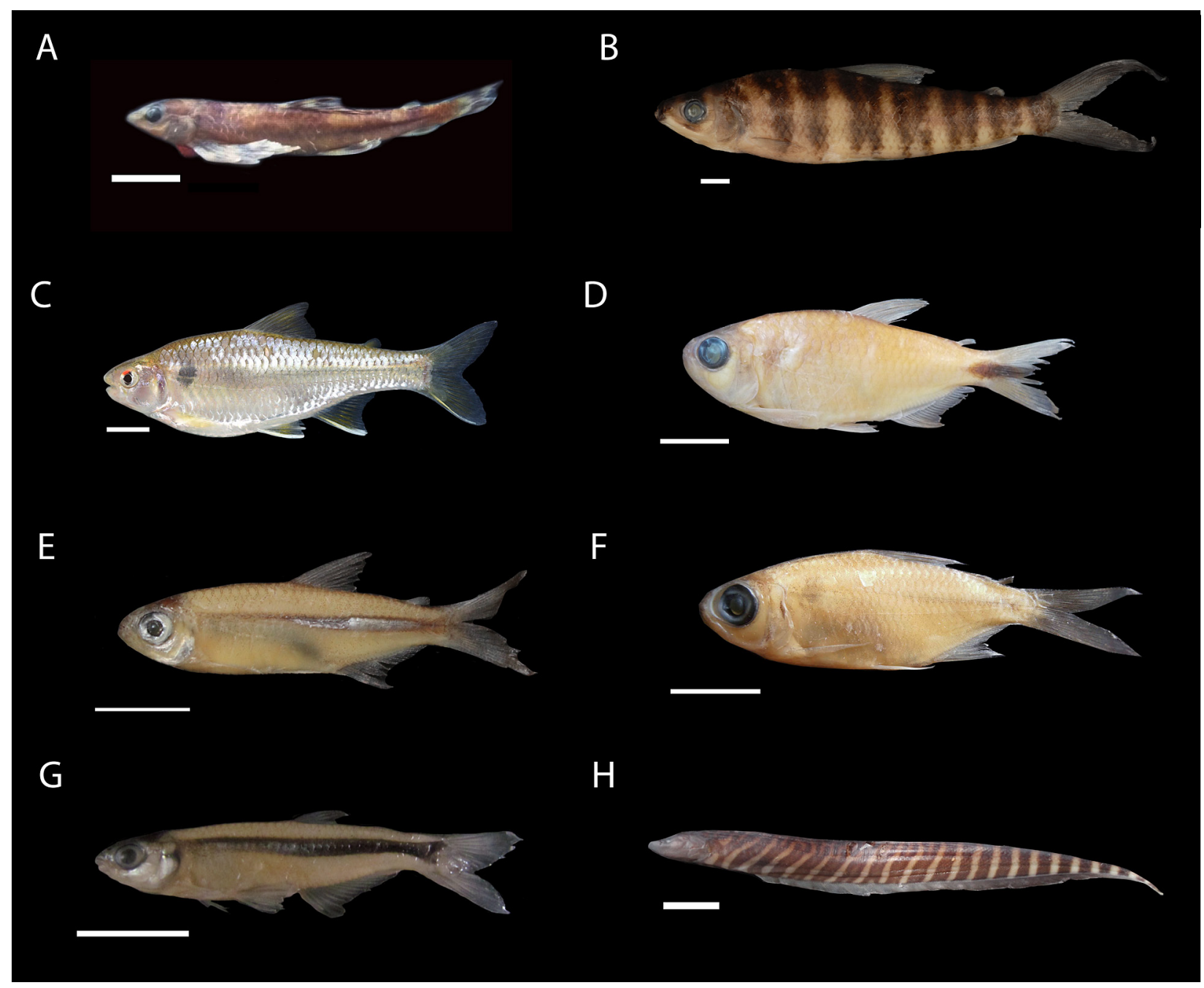

Figure 1. Characiformes and Gymnotiformes. A. Characidium crandellii. B. Leporinus altipinnis. C. Creagrutus gyrospilus. D. Moenkhausia diktyota. E. M. gracilima. F. M. lata. G. Scopaeocharax rhinodus. H. Gymnotus tiquie. Scale bars $=10 \mathrm{~mm}$. 

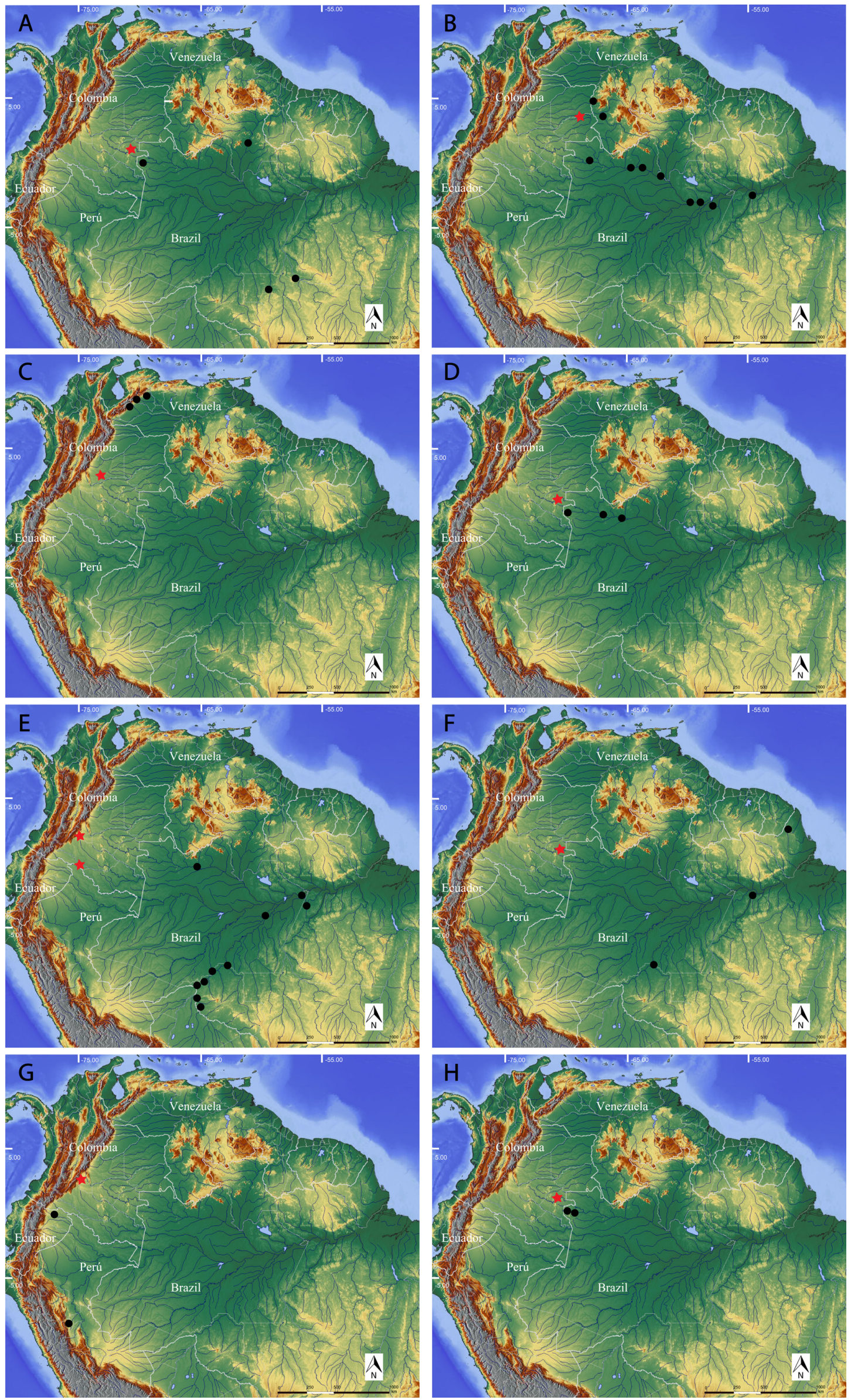

Figure 2. Localities of new records (red stars) and previous records (black cricles) for Characiformes and Gymnotiformes. A. Characidium crandellii. B. Leporinus altipinnis. C. Creagrutus gyrospilus. D. Moenkhausia diktyota. E. M. gracilima. F. M. lata. G. Scopaeocharax rhinodus. H. Gymnotus tiquie. 
(Britski and Birindelli 2016). Another character distinguishing L. altipinnis from its congeners is the pointed lobes of the caudal fin (Britski and Birindelli 2016).

Previously known distribution. In Brazil: rio Arapiuns (tributary of the lower rio Tapajós) and rio Paraconi at FLONA do Pau Rosa, Pará; rio Negro (Britski and Birindelli 2016), Amazonas. In Venezuela: río Orinoco (Britski and Birindelli 2016), Amazonas. Type locality: Jaturana creek or small lake near Barreirinha, Municipality of Parintin, Amazonas, Brazil.

Remarks. The occurrence of L. altipinnis in Colombia was expected, as it was recorded for several localities in the Rio Orinoco basin in Venezuela near the border with Colombia (Britski and Birindelli 2016).

Order Characiformes

Family Characidae

\section{Creagrutus gyrospilus Vari \& Harold, 2001}

Figures 1C, 2C

New records. COLOMBIA $• 3$ adults; Guaviare, $\mathrm{Mu}$ nicipality of San José del Guaviare, caño La Tigrera; $02.2619^{\circ} \mathrm{N}, 073.1224^{\circ} \mathrm{W}$; ca $220 \mathrm{~m}$ a.s.l.; 25 Oct. 2011; Francisco Villa leg.; found in a small terra firme stream; voucher CZUT-IC 7215.

Identification. Creagrutus gyrospilus is identified by the following combination of characters: broad premaxillary with teeth arranged as the first teeth of the primary series, more common pattern for the genus (Vari and Harold 2001), a rounded humeral blotch, and several other morphometric and meristic features (see Vari and Harold 2001).

Previously known distribution. Venezuela: western Orinoco river basin (Vari and Harold 2001). Type locality: río Saguáz, río Guanare-Apure drainage, bridge near park on road to Chabasquén, state of Portuguesa, Venezuela.

Remarks. Creagrutus gyrospilus was previously reported in western Orinoco river basin in Venezuela but was not reported in any of its tributaries in Colombia (Vari and Harold 2001). This species was already recorded from Colombia by GBIF (https://www.gbif.org/ occurrence/search?q=Creagrutus $\% 20$ gyrospilus\&country $=$ CO\&advanced $=1$ ); however, this is the first time that it is reported by a published paper.

Order Characiformes

Family Characidae

\section{Moenkhausia diktyota Lima \& Toledo-Piza, 2001} Figures 1D, 2D

New records. COLOMBIA • 1 adult; Vaupés, Municipality of Mitú, caño Yi, near the Santa Rosalía community; $01.0545^{\circ} \mathrm{N}, 070.2998^{\circ} \mathrm{W}$; ca $200 \mathrm{~m}$ a.s.l.; 29 Apr. 2013; Juan Bogotá leg.; found in a sandy small terra firme stream; voucher CIACOL 1022. • 4 adults; Department of Vaupés, Municipality of Mitú, caño Pintadillo, near the Santa Rosalía community; $01.0579^{\circ} \mathrm{N}, 070.3013^{\circ} \mathrm{W}$; 190 m a.s.l.; 1 May 2013; Juan Bogotá leg.; found in the margin of a small terra firme stream; voucher CIACOL 1023.

Identification. Moenkhausia diktyota can be distinguished from all its congeners by the combination of a reticulated color pattern, a dark stripe extending from the caudal peduncle to the middle caudal-fin rays, and an incomplete lateral line (Lima and Toledo-Piza 2001).

Previously known distribution. Brazil: upper and middle rio Negro basin (Lima and Toledo-Piza 2001). Type locality: middle rio Negro, igarapé at São João, near Santa Isabel do rio Negro, state of Amazonas, Brazil.

Remarks. This species was expected to occur in Colombia as some of Brazilian records in the rio Tiquié (a tributary of the rio Vaupés/Uaupés) were right at the border with Colombia (FCTL pers. obs.). According to what is known about this species, it seems to be restricted to small streams from the middle and upper rio Negro drainage.

\section{Order Characiformes \\ Family Characidae}

\section{Moenkhausia gracilima Eigenmann, 1908}

Figures 1E, 2E

New records. COLOMBIA • 1 adult; Caquetá, Municipality of Florencia, río Hacha, below the bridge on the road to Neiva; $01.5192^{\circ} \mathrm{N}, 075.2542^{\circ} \mathrm{W}$; ca $260 \mathrm{~m}$ a.s.1.; 19 Sep. 2015; Juan Bogotá leg.; found in the rocky margin of the river; voucher CIACOL 1722 • 1 adult; Department of Putumayo, Municipality of Puerto Leguízamo, km 8 Puerto Leguízamo-La Tagua, caño El Bufeo, near San Pedro community; $00.1494^{\circ} \mathrm{N}, 074.7558^{\circ} \mathrm{W}$; ca 210 m a.s.1.; 13 Mar. 2016; Iván González, Guber López, César Bonilla and Astrid Acosta leg.; found in a small stream; voucher CIACOL 1940.

Identification. The specimens were identified by the combination of presence of a faint humeral blotch and the dusky edges of the caudal fin, which are unique for this species among its congeners (e.g. Géry 1992; Lima et al. 2013).

Previously known distribution. Brazil: The species is widespread in the Amazon basin (Géry 1992; Lima et al. 2013). Type locality: Villa Bella, Serpa, Amazon River, state of Amazonas, Brazil.

Remarks. The specimens referenced herein were collected in Colombia in the Caquetá and Putumayo river drainages, both tributaries of the Amazon River and having an Andean origin. Previous occurrences in other regions of the Amazon suggest that the species is not restricted to systems with specific water chemistry. This species was already recorded from Colombia by GBIF (https://www.gbif.org/occurrence/ search?country=CO\&taxon_key=2352589); however, this is the first time that it is reported by a published paper. 
Order Characiformes

Family Characidae

\section{Moenkhausia lata Eigenmann, 1908}

Figures 1F, 2F

New records. COLOMBIA • 4 adults; Vaupés, Municipality of Mitú, río Vaupés; $01.24386^{\circ} \mathrm{N}, 070.2395^{\circ} \mathrm{W}$; ca 170 m a.s.1.; 27 Aug. 2012; José Cardenas and Astrid Acosta leg.; found on a sandy beach in main channel of river; voucher CIACOL 690.

Identification. The specimens were identified by the combination of a deep body, a conspicuous humeral blotch, and a dark blotch at the upper caudal lobe (Géry 1992; Lima et al. 2013).

Previously known distribution. Brazil: the species was previously recorded from the Tapajós, Madeira, and Oyapock river basins (Géry 1992; Lima et al. 2013). Type locality: lower rio Tapajós, state of Pará, Brazil.

Remarks. The species seems to be associated with deep river channel systems. It is abundant in drainages that are part of the lower Amazon river basin in Pará, Brazil (data from MCP, UF, and ZUEC collections), but it was not previously recorded in the upper Amazon. Thus, its geographic distribution is extended by more than $2000 \mathrm{~km}$. As for M. gracilima, our new data suggest that $M$. lata is not restricted to systems with specific water chemistry. This species was already recorded from Colombia by GBIF (https://www. gbif.org/occurrence/search?country=CO\&taxon_key= 2352534\&advanced=1); however, this is the first time that it is reported by a published paper.

Order Characiformes

Family Characidae

\section{Scopaeocharax rhinodus (Böhlke, 1958)}

Figures $1 \mathrm{G}, 2 \mathrm{G}$

New records. COLOMBIA • 1 adult; Caquetá, Municipality of San José del Fragua, río San Juan, below the bridge on the road from Florencia to Belén; $01.3972^{\circ} \mathrm{N}$, $075.8943^{\circ} \mathrm{W}$; ca $310 \mathrm{~m}$ a.s.1.; 14 Aug. 2018; Juan Bogotá and Iván González leg.; voucher CIACOL 3468. • 5 adults; Department of Caquetá, Municipality of Belén, quebrada La Yuca, vía Florencia-Belén de los Andaquies; $01.6075^{\circ} \mathrm{N}, 075.6392^{\circ} \mathrm{W}$; ca $280 \mathrm{~m}$ a.s.1.; 14 Aug. 2018; Juan Bogotá and Iván González leg.; found in the rocky margin of the river; voucher CIACOL 3469.

Identification. The specimens have the following combination of characters: premaxillary dentition composed of three irregular rows, maxillary uniserial, eight branched dorsal fin rays, adipose fin present, and seven branched pelvic-fin rays. Scopaeocharax rhinodus can be distinguished from its sole congener, $S$. atopodus, in presenting a more elongate body, more pointed head, and a broader midlateral stripe (Böhlke 1958: 320, fig. 1).

Previously known distribution. In Ecuador and Perú: see Ortega and Vari (1986) and Barriga (2014). Type locality: quebrada de Puente Pérez, about 1/4 mile above río Huallaga, vicinity of Tingo María, Huanuco province, Perú.

Remarks. Scopaeocharax rhinodus is restricted to the western Amazon river basin (Ortega and Vari 1986; Carvalho et al. 2011; Barriga 2014).

Order Gymnotiformes

Family Gymnotidae

\section{Gymnotus tiquie Maxime, Lima \& Albert, 2011}

Figures $1 \mathrm{H}, 2 \mathrm{H}$

New records. COLOMBIA $\bullet 1$ adult; Vaupés, Municipality of Mitú, caño Gavilán, below waterfall at community Cucura, Mitú-Raudal Santa Cruz de Waracapurí road; $01.1659^{\circ} \mathrm{N}, 070.1476^{\circ} \mathrm{W}$; ca $180 \mathrm{~m}$ a.s.1; 16 Sep. 2016; Joseph Waddell, Janzen Francesco, Nathan Lovejoy and William Crampton leg.; found below the waterfall from a terra firme stream; voucher CIACOL 2498.

Identification. The specimen was distinguished from its congeners by its elongated body and a color pattern composed of darkly pigmented, evenly spaced bands (typical of the subgenus Lamontianus), and by a wide mouth (i.e. ca 55\% HL) and a short maxilla (Craig et al. 2019).

Previously known distribution. Brazil: rio Uaupés (Maxime and Albert 2011). Type locality: rio Tiquié, comunidade de São José, Igarapé Espuma, state of Amazonas, Brazil.

Remarks. Its occurrence in Colombia was expected as this species was recorded in Brazil very near the border with Colombia.

Order Siluriformes

Family Callichthyidae

Callichthys serralabium Lehmann \& Reis, 2004 Figures 3A, 4A

New records. COLOMBIA $\bullet 1$ adult; Vaupés, Municipality of Mitú, caño Aguacatillo, tributary of the caño Yi, East from Santa Rosalía community; $01.0585^{\circ} \mathrm{N}$, 070.2911W; ca 210 m a.s.l.; 1 May 2013; Juan Bogotá leg.; found sandy in a small terra firme stream; voucher CIACOL 852

Identification. The specimen was identified by the serrated lower lip, which is the diagnostic for the species. Other characters include the eight branched rays in the pectoral fin, long anal-fin spine, and the diffuse, blotched color pattern (Lehmann and Reis 2004).

Previously known distribution. In Brazil and Venezuela: upper río Orinoco and upper río Negro basins (Lehmann and Reis 2004). Type locality: upper río Orinoco, laguna Tonina, $1 \mathrm{~km}$ upstream from La Esmeralda, state of Amazonas, Venezuela (Lehmann and Reis 2004: fig. 5).

Remarks. The occurrence in Colombia was expected, as the species was recorded in Brazil, near the border with Colombia. 


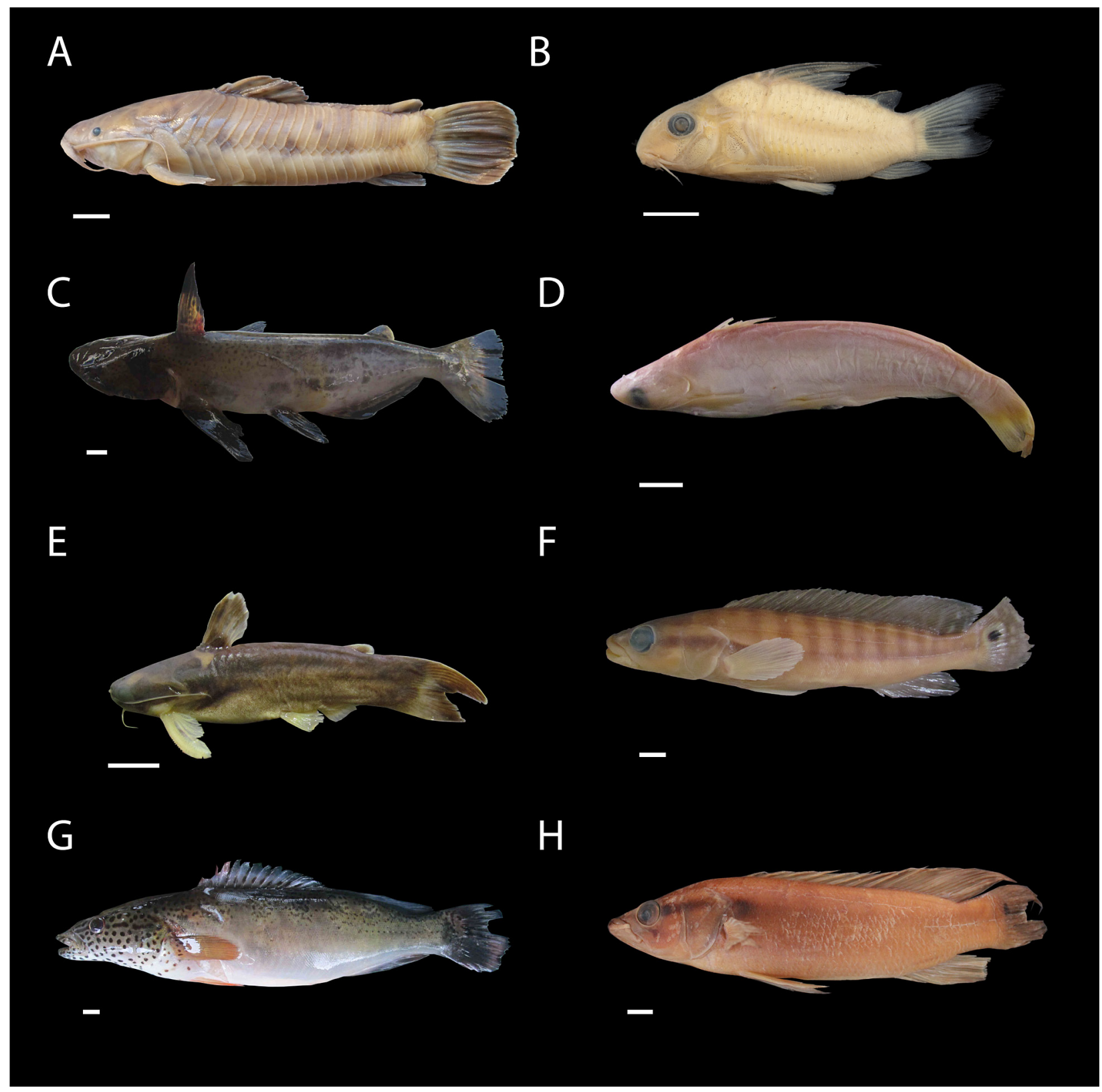

Figure 3. Siluriformes and Cichliformes. A. Callichthys serralabium. B. Corydoras armatus. C. Ageneiosus polystictus. D. Auchenipterus britskii. E. Tatia brunnea. F. Crenicichla cincta. G. C. marmorata. H. C. proteus. Scale bars $=10 \mathrm{~mm}$

Order Siluriformes

Family Callichthyidae

\section{Corydoras armatus (Günther, 1868)}

Figures 3B, 4B

New records. COLOMBIA $\bullet 4$ adults; Amazonas, Municipality of Santa Lucía, río Cotuhé; $02.8661^{\circ} \mathrm{S}, 069.8322^{\circ}$ W; ca 70 m a.s.1.; Francisco Villa leg; voucher CZUT-IC 14727.

Identification. The specimens were identified by the following combination of characters: compressed head, maxillary barbels extending below the eye, upper series of the shields in 23 series, strong and long fin spines with the dorsal one as long as the body depth, and the anterior shields with small black dots. The very long pectoral and dorsal spines are unique to this species (Nijssen and Isbrücker 1986).
Previously known distribution. Western Amazon basin in Brazil and Peru (Nijssen and Isbrücker 1986). Type locality: río Huallaga, Amazon drainage, Peru.

Remarks. This species was already recorded from Colombia by GBIF (https://www.gbif.org/occurrence/search ?country=CO\&taxon_key=2342788); however, this is the first time that it is reported by a published paper.

\section{Order Siluriformes}

Family Auchenipteridae

\section{Ageneiosus polystictus Steindachner, 1915}

Figures 3C, 4C

New records. COLOMBIA • 2 adults; Vaupés, Municipality of Mitú, río Cuduyarí, vicinity of Garrafa community, mouth lago Camapí; $01.3039^{\circ} \mathrm{N}, 070.2791^{\circ} \mathrm{W}$; ca 180 m a.s.1.; 20 Jul. 2012; Astrid Acosta and Leonardo 

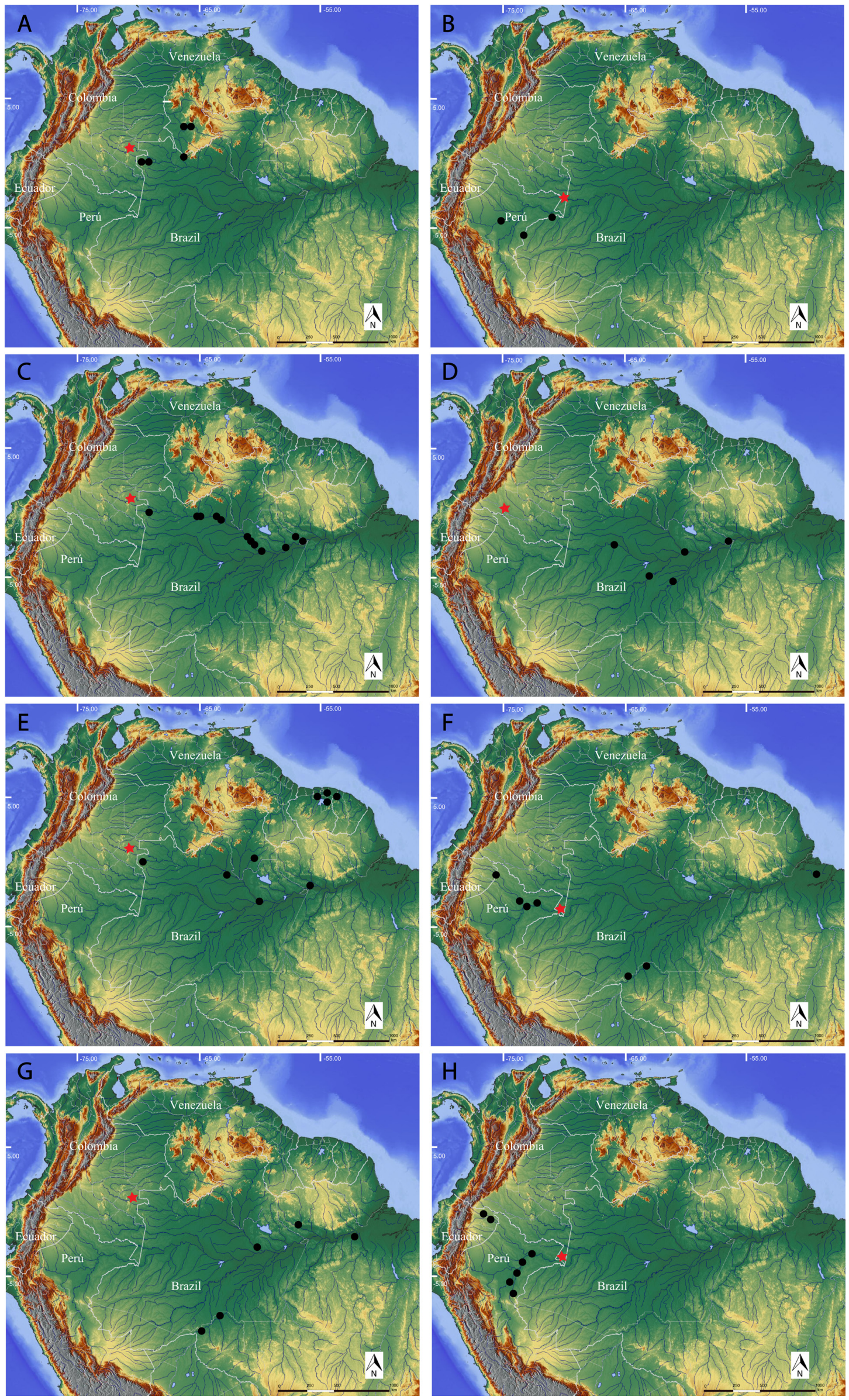

Figure 4. Localities of new records (red stars) and previous records (black circles) for Siluriformes and Cichliformes. A. Callichthys serralabium. B. Corydoras armatus. C. Ageneiosus polystictus. D. Auchenipterus britskii. E. Tatia brunnea. F. Crenicichla cincta. G. C. marmorata. H. C. proteus. 
Yepez leg.; voucher CIACOL 786. COLOMBIA • 3 adults; Department of Vaupés, Municipality of Mitú río Vaupés; $01.2439^{\circ} \mathrm{N}, 070.2395^{\circ} \mathrm{W}$; ca $160 \mathrm{~m}$ a.s.1.; 23 Nov. 2014; José Espítia and Astrid Acosta leg; voucher CIACOL 1158.

Identification. The specimens were identified by slightly emarginate caudal fin, and dark spots randomly distributed on the flanks (Ribeiro et al. 2017).

Previously known distribution. Brazil: rio Negro and middle Amazon basin (Ribeiro et al. 2017). Type locality: mouth of rio Negro, Amazon system, Brazil.

Order Siluriformes

Family Auchenipteridae

\section{Auchenipterus britskii Ferraris \& Vari, 1999} Figures 3D, 4D

New records. COLOMBIA • 1 adult; Caquetá, Municipality of Solano, río Consaya; $00.5331^{\circ} \mathrm{N}, 075.1000^{\circ} \mathrm{W}$; ca 200 m a.s.l.; 9 Oct. 2010; Paula Sánchez leg; voucher CIACOL 585.

Identification. The specimen was identified by the following combination of characters proposed by Ferraris and Vari (1999): mental barbels not reaching past pelvic-fin base, membrane from inner ray of pelvic fin attached to body lateral to ventral midline at the level of the anus, anal-fin origin located posterior to middle of standard length, anal-fin base length less than distance between snout and pelvic-fin origin, caudal fin without distinct dark chevron at base of upper and lower lobes, pectoral fin with 11 branched rays; pelvic fin with 12 branched rays, and a low number (34-37) of branched anal-fin rays.

Previously known distribution. Brazil: middle and western Amazon river basin (Ferraris and Vari 1999). Type locality: Lago Janauacá, vicinity of rio Solimões, ca $03.283221^{\circ} \mathrm{S}, 060.171213^{\circ} \mathrm{W}$, state of Amazonas, Brazil.

Order Siluriformes

Family Auchenipteridae

\section{Tatia brunnea Mees, 1974}

Figures 3E, 4E

New records. COLOMBIA $• 5$ adults; Vaupés, Municipality of Mitú, caño Yi, $20 \mathrm{~m}$ downriver from main port of Santa Rosalía community; $01.0580^{\circ} \mathrm{N}, 070.3013^{\circ} \mathrm{W}$; 190 m a.s.1.; 24 Jun. 2012; Astrid Acosta and Jesús Damaso leg.; voucher CIACOL 796. 5 adults; Department of Vaupés, Municipality of Mitú, caño Yi, near Santa Rosalía community; $01.0580^{\circ} \mathrm{N}, 070.3013^{\circ} \mathrm{W} ; 190 \mathrm{~m}$ a.s.l.; 29 Apr. 2013; Juan Bogotá leg.; found at a small streams margin; voucher CIACOL 869. • 17 adults; Department of Vaupés, Municipality of Mitú, stream at $\mathrm{km} 8$ on the road Mitú-Monfor, Ceima-San Pablo place; 1.212083 ${ }^{\circ} \mathrm{N}, 070.173583^{\circ} \mathrm{W}$; ca $190 \mathrm{~m}$ a.s.1.; 4 May 2013; Juan Bogotá leg.; found at a small stream margin; voucher

\section{CIACOL 867.}

Identification. The specimens were identified by the following combination of characters proposed by Sarmento-Soares and Martins-Pinheiro (2008): snout length $36.1-44.3 \%$ HL; eye $21.4-26.5 \%$ HL; head width $86.6-$ 93.4\% HL; mouth width 54.0-59.7\% HL; postcleithral process long, 15.6-21.8\% SL, almost reaching vertical through origin of dorsal fin; caudal peduncle depth greater than $13.6 \% \mathrm{SL}$; adult size greater than $48.0 \mathrm{~mm}$ $\mathrm{SL}$; vomerine teeth absent; pectoral-fin spine with transverse dark bands; pectoral fin usually with one spine and five soft rays; branched anal-fin rays seven or eight; mature male genital papilla without skin flap around deferent duct; notch absent from distal margin of modified anal fin in mature males; modified anal fin in mature males with sharp distal tip, first unbranched ray divided into three or four segments, one to three short antrorse denticulations along distal anterior margin of third unbranched ray, and third anal-fin ray comparatively long, between 7.5 and $10.0 \%$ SL; border of mouth whitish, contrasting with dark head; posterior border of nuchal shield usually whitish or pale; and caudal fin usually whitish with scattered dark brown blotches.

Previously known distribution. In Brazil, French Guyana, and Suriname: Negro and Trombetas river basins (Le Bail et al. 2000; Sarmento-Soares and Martins-Pinheiro 2008). Type locality: Brokopondo district, Compagnie Kreek, Suriname.

Remarks. This species was already recorded from Colombia by GBIF (https://www.gbif.org/occurrence/search ?q=Tatia $\% 20$ brunnea\&country $=$ CO\&taxon_key $=235$ $2534 \&$ advanced $=1$ ); however, this is the first time that it is reported by a published paper.

\section{Order Cichliformes \\ Family Cichlidae}

\section{Crenicichla cincta Regan, 1905 \\ Figures 3F, 4F}

New records. COLOMBIA -1 adult; Amazonas, Municipality of Puerto Nariño, Parque Nacional Natural Amacayacu, elbow in río Amacayacu, $200 \mathrm{~m}$ before La Balsa; $03.8054^{\circ} \mathrm{S}, 070.3061^{\circ} \mathrm{W} ; 80 \mathrm{~m}$ a.s.1.; 13 Oct. 2008; Camilo Fuentes, Gabriel Aricari and Gabriel Vela leg.; voucher CIACOL 435.

Identification. The specimen (CIACOL 435, Fig. 3G) was identified by the color pattern composed of 10 vertical bands on upper half of the body and a longitudinal dark stripe along the midbody. The color pattern is unique within the Crenicichla lugubris species group (Kullander 1986; Da Graça et al. 2013).

Previously known distribution. Amazon river basin in Brazil, Ecuador, and Peru (Kullander 1986; Da Graça et al. 2013). Type locality: Marajó Island, state of Pará, Brazil. 
Order Cichliformes

Family Cichlidae

\section{Crenicichla marmorata Pellegrin, 1904}

Figures 3G, 4G

New records. COLOMBIA $• 3$ adults; Vaupés, Municipality of Mitú, río Vaupés; $01.2439^{\circ} \mathrm{N}, 070.2395^{\circ} \mathrm{W}$; ca 170 m a.s.1.; 126 Nov. 2014; José Espitia and Astrid Acosta leg; voucher CIACOL 928.

Identification. The specimens were identified by possessing ctenoid scales on flanks of the body, maxilla extending at least to the anterior margin of the eye, and color pattern composed of dark spots on head and dorsal region of the body.

Previously known distribution. Brazil: widely distributed in the Amazon river basin (Ploeg 1987; Da Graça et al. 2013). Type locality: no locality [Rio Trombetas, Amazon], state of Amazonas, Brazil.

Remarks. This species was already recorded from Colombia by GBIF (https://www.gbif.org/occurrence/ search?country=CO\&taxon_key=2370986); however, this is the first time that it is reported by a published paper.

Order Cichliformes

Family Cichlidae

\section{Crenicichla proteus Cope, 1872}

Figures $3 \mathrm{H}, 4 \mathrm{H}$

New records. COLOMBIA 1 specimen; Amazonas, Municipality of, Leticia, Lago I, lagoon system of Yahuarcaca; $04.1933^{\circ} \mathrm{S}, 069.9531^{\circ} \mathrm{W}$; ca $70 \mathrm{~m}$ a.s.l.; $13 \mathrm{Jul}$. 1995; Fernando Rodríguez leg.; voucher CIACOL 311.• 3 specimens (CIACOL 1362); Department of Amazonas, Municipality of, Leticia, caño de Yahuarcaca; $04.1945^{\circ} \mathrm{S}$, 069.9497 W; ca 80 m a.s.1.; 13 Sep. 2014; Gabriel Aricari leg; voucher CIACOL 1362.

Identification. The species belonging to the Crenicichla saxatilis-group, are characterized by the relatively large scales and consequently lower scales counts, and the presence of a humeral blotch. Among the Crenicichla species of the $C$. saxatilis group occurring in the western Amazon Basin, it is distinguished primarily by the low scale counts, a dusky notch below the eye, and the humeral blotch below the lateral line (Kullander 1986; Varella et al. 2018)

Previously known distribution. Amazon river basin in Brazil, Ecuador, and Peru (Kullander 1986). Previous records of Crenicichla saxatilis from Colombian Amazon (e.g., Galvis et al. 2006) likely belong to this species. Type locality: río Ambyiacu, Peru.

\section{Discussion}

The Neotropical region is well recognized as a primary source of biodiversity (Antonelli et al. 2018), and specifically, it has the most species-rich freshwater ichthyofauna on Earth (Albert and Reis 2011; Reis et al. 2016). However, a comprehensive understanding of how species are distributed among its aquatic ecosystems still far off (Oberdorff et al. 2019). Much of what is known about the fishes of the Neotropical region is based on the material deposited in the collections. Scientific reference collections are essential for documenting biodiversity. Our new data contribute to a general understanding of how species are spatially distributed, which is fundamental for understanding historical drivers of species diversity of this megadiverse fauna (Oberdorff et al. 2019).

The relatively large number of species newly recorded from Colombia may reflect the general lack of ichthyological studies that have been done in the Colombian Amazon. Vast areas of the Colombian Amazon are still unexplored, especially in remote, almost inaccessible areas, where a meaningful approximation of the actual species richness is still not possible. However, some of the species that we report, such as Gymnotus tiquie and Ageneiosus polystictus, were expected to be in Colombian territory, as they were known to occur in the same river systems in adjacent countries. Additional ichthyological studies in the Colombian Amazon are important to improve our understanding of fish distributions there.

Scientific collections like those investigated here are fundamental for understanding patterns of biodiversity (Arbeláez-Cortés et al. 2017), as well as other collections-based research; however, the scientific importance of collections it is not always well appreciated (Carvalho et al. 2008), and most collections face long-term support and maintenance issues (Poss and Collette 2008). With improved support, the deposition, curation, and maintenance of specimens should improve, and those improvements will ultimately allow for reliable information to be available and used in various research areas such as taxonomy, systematics, ecology, and biogeography.

Natural ecosystems in the Neotropics are increasingly threatened by habitat loss (e.g. deforestation, mining, and hydroelectric dam construction) and degradation (e.g. climate change). Management and conservation plans are still lacking (Abell et al. 2008; Reis et al. 2016; Machado-Allison 2017). Our new records will complement baseline data for a general understanding of the origin and maintenance of the largest vertebrate nonmarine assemblage, and how it can be protected.

\section{Acknowledgements}

This study was funded by the Grupo de Investigación en Ecosistemas Acuáticos Amazónicos of the Sinchi Institute. Iván González and Marcela Núñez supported us during our fieldwork. Donald Taphorn helped during taxonomic revisions. Members of the headquarters of the Sinchi Institute at Mitú, Vaupés, and Puerto Leguizamo for logistic and field support. Joe Waddell helped revise the English. Jorge García photographed the specimens in the CZUT-IC collection. 


\section{Authors' Contributions}

JDBG, AAC, FAVN, and EAC collected specimens; JDBG, FCTL, CD, AAC, and FAVN identified the specimens; JDBG, FCTL, and CD wrote the manuscript.

\section{References}

Abell R, Thieme ML, Revenga C, Bryer M, Kottelat M, Bogutskaya N, Coad B, Mandrak N, Balderas SC, Bussing W, Stiassny MLJ, Skelton P, Allen GR, Unmack P, Naseka A, Ng R, Sindorf N, Robertson J, Armijo E, Higgins J V, Heibel TJ, Wikramanayake E, Olson D, Lopez HL, Reis RE, Lundberg JG, Perez MHS, Petry P (2008) Freshwater ecoregions of the world: a new map of biogeographic units for freshwater biodiversity conservation. Bioscience 58 (5): 403-414. https://doi.org/10.1641/B580507

Albert JS, Reis RE (2011) Historical biogeography of Neotropical freshwater fishes. University of California Press, Berkeley, 406 pp.

Antonelli A, Zizka A, Carvalho FA, Scharn R, Bacon CD, Silvestro D, Condamine FL (2018) Amazonia is the primary source of Neotropical biodiversity. Proceedings of the National Academy of Sciences of the United States of America 115: 6034-6039. https:// doi.org/10.1073/pnas.1713819115

Arbeláez-Cortés E, Acosta-Galvis AR, DoNascimiento C, EspitiaReina D, González-Alvarado A, Medina CA (2017) Knowledge linked to museum specimen vouchers: measuring scientific production from a major biological collection in Colombia. Scientometrics 112: 1323-1341. https://doi.org/10.1007/s11192-017-2461-4

Le Bail P-Y, Keith P, Planquette P (2000) Atlas des poissons d'eau douce de Guyane. Tome 2, fascicule II: Siluriformes. Collection du Patrimoine Naturel, Muséum National d'Historie Naturelle, Service du Patrimoine Naturel, Institut D’Ecologia et de Gestion de la Biodiversité, Paris, 207 pp.

Barriga R (2014) Lista de peces de agua dulce e intermareales del Ecuador. Revista Politécnica 30: 83-119.

Böhlke JE (1958) Results of the Catherwood Foundation Peruvian Amazon Expedition. The descriptions of two new xenurobryconine characids. Copeia 1958 (4): 318-325. https://doi.org/10.2307/ 1439965

Britski HA, Birindelli JLO (2016) Redescription of Leporinus altipinnis, a senior synonym of L. falcipinnis, and comments on L. holostictus (Characiformes: Anostomidae). Ichthyological Exploration of Freshwaters 22: 25-40.

Buckup PA (1993) Phylogenetic interrelationships and reductive evolution in Neotropical characidiin fishes (Characiformes, Ostariophysi). Cladistics 9 (3): 305-341. https://doi.org/10.1111/j.10960031.1993.tb00227.x

Burley HM, Mokany K, Ferrier S, Laffan SW, Williams KJ, Harwood TD (2016) Macroecological scale effects of biodiversity on ecosystem functions under environmental change. Ecology and Evolution 6 (8): 2579-2593. https://doi.org/10.1002/ece3.2036

Carvalho MRD, Bockmann FA, Amorim DS, Brandao CRF (2008) Systematics must embrace comparative biology and evolution, not speed and automation. Evolutionary Biology 35: 150-157. https:// doi.org/10.1007/s11692-008-9018-7

Carvalho TP, Espino J, Máxime E, Quispe R, Rengifo B, Ortega H, Albert JS (2011) Fishes from the Lower Urubamba river near Sepahua, Amazon Basin, Peru. Check List 7 (4): 413-442. https://doi. org/10.15560/7.4.413

Castello L, Mcgrath DG, Hess LL, Coe MT, Lefebvre PA, Petry P, Macedo MN, Renó VF, Arantes CC (2013) The vulnerability of Amazon freshwater ecosystems. Conservation Letters 6 (4): 217 229. https://doi.org/10.1111/conl.12008

Chapman AD, Busby JR (1994) Linking plant species information to continental biodiversity inventory, climate and environmental monitoring. In: Miller RI (Ed.) Mapping the diversity of nature.
Springer, Dordrecht, 179-195. https://doi.org/10.1007/978-94-0110719-8 11

Craig JM, Kim LY, Tagliacollo VA, Albert JS (2019) Phylogenetic revision of Gymnotidae (Teleostei: Gymnotiformes), with descriptions of six subgenera. PLoS ONE 14 (11): e0224599. https://doi. org/10.1371/journal.pone.0224599

DoNascimiento C, Herrera EE, Herrera G, Ortega-Lara A, VillaNavarro F, Usma JS, Maldonado-Ocampo JA (2017) Checklist of the freshwater fishes of Colombia: a DwC alternative to the updating problem. ZooKeys 138: 25-138. https://doi.org/10.3897/zoo keys.708.13897

Ferraris CJ, Santana CD De, Vari RP (2017) Checklist of Gymnotiformes (Osteichthyes: Ostariophysi) and catalogue of primary types. Neotropical Ichthyology 15 (1): el60067. https://doi.org/ 10.1590/1982-0224-20160067

Ferraris CJJ, Vari R (1999) The South American catfish genus Auchenipterus Valenciennes, 1840 (Ostariophysi: Siluriformes: Auchenipteridae): monophyly and relationships, with a revisionary study. Zoological Journal of the Linnean Society 126 (4): 387 450. https://doi.org/10.1111/j.1096-3642.1999.tb00156.x

Flausino-Junior N, Machado FA, Zuanon JS, Ferreira EJ (2016) The fish fauna of sessile hydrophytes stands (Mourera spp.: Podostemaceae) in the Dardanelos Waterfalls, Rio Aripuanã, Brazil. Aqua, International Journal of Ichthyology 22 (3): 133-144.

Fricke R, Eschmeyer WN, Laan van der R (2020) Eschmeyer's catalog of fishes: genera, species, references. California Academy of Sciences, San Francisco, CA. http://researcharchive.calacademy.org/ research/ichtyology/catalog/fishcatmain.asp. Accessed on: 20208-30.

Galvis G, Mojica JI, Duque SR, Castellanos C, Sánchez-Duarte P, Arce M, Gutiérrez A, Jiménez LF, Santos M, Vejarano S, Arbeláez F, Prieto E, Leiva M (2006) Peces del alto Amazonas - región de Leticia. Serie de guias tropicales de campo 5. Conservación Internacional, Bogotá, DC, 491 pp.

Géry J (1992) Descriptions de deux nouvelles espèces proches de Moenkhausia lepidura (Kner) (Poissons, Characiformes, Tetragonopterinae), avec une revue du groupe. Revue Française d'Aquariologie 19: 69-78.

Da Graça WJ, Varella HR, Vieira FG (2013) Cichlidae. In: Queiroz LJ, Torrente-Vilara G, Ohara WM, Pires THS, Zuanon J, Doria CRC (Eds) Peixes do rio Madeira. Dialeto, São Paulo, 331-389.

Humboldt I de I de RBA von (2000) Colombia mega diversa: cinco años explorando la riqueza de un país biodiverso. Bogotá, DC, Colombia, 295 pp.

Junk WJ, Soares MGM, Bayley PB (2007) Freshwater fishes of the Amazon river basin: their biodiversity, fisheries, and habitats. Aquatic Ecosystem Health \& Management 10 (2): 153-173. https:// doi.org/10.1080/14634980701351023

Kullander SO (1986) Cichlid fishes of the Amazon river drainage of Peru. Swedish Museum of Natural History, Stockholm, $431 \mathrm{pp}$.

Lehmann P, Reis RE (2004) Callichthys serralabium: a new species of Neotropical catfish from the Upper Orinoco and Negro rivers (Siluriformes: Callichthyidae). Copeia 2004 (2): 336-343. https://doi org/10.1643/CI-03-129R

Leveque C, Oberdorff T, Paugy D, Stiassny MLJ, Tedesco PA (2008) Global diversity of fish (Pisces) in freshwater. Hydrobiologia 595: 545-567. https://doi.org/10.1007/s10750-007-9034-0

Lima FCT, Toledo-Piza M (2001) News of Moenkhausia (Characiformes: Characidae) from the Rio Negro of Brazil. Copeia 2001 (4): 1058-1063. https://doi.org/10.1643/0045-8511(2001)001[1058:nso mcc]2.0.co;2

Lima FCT, Pires THS, Ohara WM, Jerep FC, Carvalho FR, Marinho MMF, Zuanon J (2013) Characidae. In: Queiroz LJ, TorrenteVilara G, Ohara WM, Pires THS, Zuanon J, Doria CRC (Eds) Peixes do rio Madeira. Dialeto, São Paulo, 213-395.

Lima FCT, Ramos L, Barreto T, Cabalzar A, Tenório G, Barbosa A, Tenório F, Resende AS, Lopes M (2005) Peixes do alto Tiquié: ictiologia e conhecimentos dos tuyuka e tukano. In: Cabalzar A 
(Ed), Peixe e gente no alto rio Tiquié: conhecimentos tukano/ tuyuka, ictiologia/etnologia. Instituto Socioambiental, São Paulo, 111-282.

Lomolino M V., Riddle BR, Whittaker RJ, Brown JH (2010) Biogeography. Fourth. Sinauer Associates, Sunderland, MA, 878 pp.

Lundberg J (2001) Freshwater richness of the Amazon. Natural History 110 : $36-43$.

Machado-Allison A (2017) River conservation in Venezuela: a review. Journal of Aquaculture \& Marine Biology 5: 00105. https:/doi. org/10.15406/jamb.2017.05.00105

Maxime EL, Albert JS (2011) A new species of Gymnotus (Gymnotiformes: Gymnotidae) from the Fitzcarrald Arch of southeastern Peru. Neotropical Ichthyology 7: 579-585. https://doi.org/10.1590/ S1679-62252009000400004

Morrone JJ (2006) Biogeographic areas and transition zones of Latin America and the Caribbean Islands based on panbiogeographic and cladistic analyses of the entomofauna. Annual Review Entomology 51: 467-94. https://doi.org/10.1146/annurev. ento.50.071803.130447

Nijssen H, Isbrücker IJH (1986) Review of the genus Corydoras from Peru and Ecuador (Pisces, Siluriformes, Callichthyidae). Studies on Neotropical Fauna and Environment 21: 1-68. https://doi.org/ 10.1080/01650528609360697

Oberdorff T, Dias MS, Jézéquel C, Albert JS, Arantes CC, Bigorne R, Carvajal-Valleros FM, De Wever A, Frederico RG, Hidalgo M, Hugueny B, Leprieur F, Maldonado M, Maldonado-Ocampo J, Martens K, Ortega H, Sarmiento J, Tedesco PA, Torrente-Vilara G, Winemiller KO, Zuanon J (2019) Unexpected fish diversity gradients in the Amazon basin. Science Advances 5: 1-10. https:/ doi.org/10.1126/sciadv.aav8681

Ohara WM, Lima FCT, Salvador GN, Andrade MC (2017) Peixes do rio Teles Pires. Guia de identificação. Grafica e Editora Amazonas, Goiânia, 408 pp.

Ortega H, Vari RP (1986) Annotated checklist of the freshwater fishes of Peru. Smithsonian Contributions to Zoology 437: 1-25. https:// doi.org/10.5479/si.00810282.437

Papavero N (1999) Herramientas prácticas para el ejercicio de la taxonomía zoológica. Ediciones Científicas Universitarias UNAM, Fondo de Cultura Económica, México, 328 pp.

Pimm SL, Jenkins CN, Abell R, Brooks TM, Gittleman JL, Joppa LN, Raven PH, Roberts CM, Sexton JO (2014) The biodiversity of species and their rates of extinction, distribution, and protection. Science 344 (6187): 987-987. https://doi.org/10.1126/science.1246752

Ploeg A (1987) Crenicichla marmorata Pellegrin du bassin du Rio Trombetas, Brésil, nouvelle descripcion illustré (Pisces, Perciformes, Cichlidae). Revue Française d'Aquariologie 14: 85-88.

Poss SG, Collette BB (2008) Second survey of fish collections in the United States and Canada. Copeia 1995 (1): 48-70. https://doi. org/10.2307/1446799

Prance GT (1994) A comparisson of the efficacy of higher taxa and species numbers in the assesmentof biodiversity in the Neotropics. Philosophical Transactions: Biological Sciences 345 (1311): 89-99. https://doi.org/10.1098/rstb.1994.0090

Reis RE, Kullander SO, Ferraris CJ (2003) Checklist of the Freshwater Fishes of South and Central America. EDIPUCRS, Porto Alegre, Brazil, 729 pp.

Reis RE, Albert JS, Di Dario F, Mincarone MM, Petry P, Rocha LA (2016) Fish biodiversity and conservation in South America. Journal of Fish Biology 89: 12-47. https://doi.org/10.1111/jfb.13016

Ribeiro FRV, Rapp Py-Daniel LH, Walsh SJ (2017) Taxonomic revision of the South American catfish genus Ageneiosus (Siluriformes: Auchenipteridae) with the description of four new species. Journal of Fish Biology 90: 1388-1478. https://doi.org/10.1111/ jfb. 13246

Röpke CP, Amadio S, Zuanon J, Ferreira EJG, De Deus CP, Pires THS, Winemiller KO (2017) Simultaneous abrupt shifts in hydrology and fish assemblage structure in a floodplain lake in the central Amazon. Scientific Reports 7: 1-10. https://doi.org/10.1038/ srep40170

Sabaj MH (2016) Standard symbolic codes for institutional resource collections in herpetology and ichthyology: an online reference. Version 6.5. 5: 802-832. American Society of Ichthyologists and Herpetologists, Washington, DC. https://asih.org/sites/default/ files/documents/symbolic_codes_for_collections_v6.5_2016.pdf. Accessed on: 2017-10-1.

Sarmento-Soares LM, Martins-Pinheiro RF (2008) A systematic revision of Tatia (Siluriformes: Auchenipteridae: Centromochlinae). Neotropical Ichthyology 6: 495-542. https://doi.org/10.1590/ S1679-62252008000300022

Schindel DE, Cook JA (2018) The next generation of natural history collections. PLoS Biology 16 (7). https://doi.org/10.1371/journal. pbio. 2006125

Seberg O, Humphries CJ, Knapp S, Stevenson DW, Petersen G, Scharff N, Andersen NM (2003) Shortcuts in systematics? A commentary on DNA-based taxonomy. Trends in Ecology and Evolution 18: 63-65. https://doi.org/10.1016/S0169-5347(02)00059-9

Varella HR, Loeb M V, Lima FCT, Kullander SO (2018) Crenicichla ploegi, a new species of pike-cichlid of the $C$. saxatilis group from the rio Juruena and upper rio Paraguai basins in Brazil, with an updated diagnosis and biogeographical comments on the group ( $\mathrm{Te}-$ leostei: Cichlidae). Zootaxa 4377 (3): 361-386. https://doi.org/10. 11646/zootaxa.4377.3.3

Vari RP, Harold AS (2001) Phylogenetic study of the Neotropical fish genera Creagrutus Günther and Piabina Reinhardt (Teleostei: Ostariophysi: Characiformes), with revision of the Cis-Andean species. Smithsonian Contributions to Zoology 613: 1-239. https://doi. org/10.5479/si.00810282.613

Watanabe ME (2019) The evolution of natural history collections: new research tools move specimens, data to center stage. BioScience 69: 163-169. https://doi.org/10.1093/biosci/biy163 